\title{
Damian Gałuszka
}

Instytut Socjologii Uniwersytetu Jagiellońskiego w Krakowie

\section{Dorota Żuchowska-Skiba}

AGH, Akademia Górniczo-Hutnicza w Krakowie

\section{Niepełnosprawność w grach wideo - omówienie na przykładach wybranych wirtualnych postaci}

DOI: http://dx.doi.org/10.18778/1733-8069.14.3.06

Abstrakt Obrazy niepełnosprawności obecne w mediach w istotny sposób wpływają na postrzeganie osób z niepełnosprawnościami. W oparciu o nie kształtują się stereotypowe wyobrażenia, które przekładają się na postawy oraz oczekiwania, jakie w stosunku do tej kategorii społecznej ma znaczna częśc społeczeństwa. Dotychczasowe badania koncentrowały się na ukazywaniu obrazów osób z niepełnosprawnościami w tradycyjnych mediach. Tymczasem we współczesnej kulturze popularnej coraz większą rolę odgrywają nowe media, $\mathrm{w}$ tym gry wideo. W związku z tym dziś istotnego znaczenia nabiera zbadanie sposobów, w jakie są w nich ukazywane postacie z niepełnosprawnościami.

Zasadniczym celem artykułu jest odtworzenie typowych wizerunków postaci z niepełnosprawnościami w grach wideo, co pozwoli na pokazanie, na ile budowane obrazy utrwalają lub zmieniaja istniejące stereotypy. Analizie poddano wybrane gry wideo, w których pojawiają się bohaterowie z niepełnosprawnością. Badanie oparto na analizie kodów kulturowych. Metoda ta została zaadaptowana do badania specyficznego medium, jakim są gry wideo, które angażują użytkownika w proces tworzenia postaci i podejmowanych przez nią działań w świecie gry.

Słowa kluczowe gry wideo, niepełnosprawność, stereotypy

Damian Gałuszka, absolwent Wydziału Humanistycznego AGH, a obecnie doktorant w Instytucie Socjologii UJ. Autor kilkunastu publikacji naukowych (między innymi w „Studiach Socjologicznych", „Kulturze i Edukacji” oraz „Homo Ludens"), w tym współredaktor dwóch książek: „Technologiczno-społeczne oblicza XXI wieku” oraz „Technokultura: transhumanizm i sztuka cyfrowa". Wyróżniany za swoje osią- gnięcia naukowe, między innymi nagrodą I stopnia Polskiego Towarzystwa Socjologicznego w konkursie im. F. Znanieckiego w roku 2017. Związany z Ośrodkiem Badań Groznawczych Wydziału Polonistyki UJ, Collegium Invisibile oraz Polskim Towarzystwem Edukacji Medialnej. W 2017 r. opublikował swoja książkę pt. „Gry wideo w środowisku rodzinnym. Diagnoza i rekomendacje" (do pobrania ze strony www.grywrodzinie.pl).

\section{Adres kontaktowy:}

Instytut Socjologii UJ,

Grodzka 52, 30-962 Kraków

e-mail: d.a.galuszka@gmail.com.

Dorota Żuchowska-Skiba, doktor na Wydziale Humanistycznym AGH w Krakowie. Jej zainteresowania naukowe łączą analizę nowych mediów z perspektywą działań zbiorowych podejmowanych w rzeczywistości społecznej i wirtualnej. Szczególną uwagę koncentruje na niepełno-

\section{Ewolucja w przedstawianiu}

niepełnosprawności w kulturze masowej

Społecznie podzielane postrzeganie normalności wyrastające $\mathrm{z}$ dominującej kultury i odrzucanie wszystkiego, co stanowi odstępstwo od niej było jednym z ważnych elementów powodujących na przestrzeni wieków wykluczenie osób z niepełnosprawnościami ze społeczeństw kręgu kultury zachodniej (Barnes 2010: 20). Historycznie rzecz ujmując, wynikało to z faktu, że osoby niepełnosprawne ze względu na swoje deficyty nie mieściły się $\mathrm{w}$ dominującym obrazie normalności (Stiker 1999: 3). W takim ujęciu niepełnosprawność nie dotyczyła wyłącznie dysfunkcji fizycznych lub psychicznych jednostek, ale ich relacji z otoczeniem społecznym (Hunt 1996: 146). Stanowiła ona efekt obowiązujących norm mających swoje źródło w kulturze, która dostarcza publicznych i ujednoliconych wartości podzielanych przez daną wspólnotę (Douglas 2007: 80). Tak rozumiana niepełnosprawność była wynikiem narzuconych kulturowo wzorów normalności (Davis 1995). Osoby odbiegające od powszechnie akceptowanego wzoru normalności stawały się nosicielami piętna (por. Goffman 2005) sprawności i aktywności społecznej, publicznej i obywatelskiej tej kategorii społecznej w dobie zmian zachodzących we współczesnych społeczeństwach pod wpływem nowych technologii oraz wzrostu znaczenia praw człowieka.

\section{Adres kontaktowy:}

Akademia Górniczo-Hutnicza im. St. Staszica

Wydział Humanistyczny

ul. Gramatyka 8a, 30-071 Kraków

e-mail: zuchowskadorota@gmail.com tywnych cech jednostkom lub zbiorowością społecznym, skutkującym ich wykluczeniem z głównego nurtu życia społecznego. Osoby noszące piętno budziły niechęć i były traktowane jako gorsze, co powodowało usuwanie ich na margines społeczeństwa (Goffman 2005: 34-35). Stawały się one bohaterami mitów i popularnych opowiadań, w których odgrywały rolę jako egzemplifikacja dla powszechnie podzielanych wartości i skutków odstępstwa od nich (Turner 1969: 110). Prowadzone w XX wieku badania nad przedstawieniami osób niepełnosprawnych $\mathrm{w}$ tekstach kultury wskazywały na budowanie w nich niekorzystnego obrazu niepełnosprawności (Shakespeare 1994). W analizach mieszczących się $\mathrm{w}$ tym obszarze osoby niepełnosprawne ukazywane były jako: „potwory”, jednostki naznaczone przez diabła lub złe siły albo kryminaliści (Longmore 1987). Złoczyńcy w popularnych książkach zwykle mieli jakąś niepełnosprawność, na przykład kapitan Hak, a czarownice były nieatrakcyjne fizycznie i zdeformowane (por. Shearer 1981). Badania te opierają się na przykładach, które skupiają się na prezentowaniu negatywnych przedstawień niepełnosprawności, nie 
ukazując całego spektrum reprezentacji tej kategorii społecznej w mediach. Inny charakter miały badania Leonarda Kriegela (1987), który w oparciu o analizę literatury zachodniej odtworzył katalog obrazów osoby niepełnosprawnej jako: (1) „szaleńca” zagrażającego społeczeństwu; (2) osoby zależnej od wsparcia ze strony sprawnego społeczeństwa, która jest pogodzona ze swoim losem; (3) realistyczny, ukazujący osobę z dysfunkcjami w kontekście codziennych problemów i przeżyć; (4) „super” niepełnosprawnego, który imponuje swoimi osiągnięciami. Typologię tę rozszerzył Colin Barnes (1992), który, opierając się na odtworzonych dzięki analizie tekstów kultury książek, filmów kinowych i telewizyjnych, artykułów w prasie, programów telewizyjnych - i obecnych w nich obrazów niepełnosprawności, wyróżnił dwanaście stereotypów, które wpływają na postrzeganie osób z niepełnosprawnościami w społeczeństwach. Osoby niepełnosprawne w mediach były ukazywane jako godne współczucia i opisywane w sposób patetyczny - jako mężnie znoszące cierpienie i trudności. Prezentowano je też jako ofiary przemocy oraz obiekty żartów, były też przedstawiane jako „super kaleki", które dokonują nieprzeciętnych czynów i osiągają cele niedostępne dla większości osób sprawnych. Osoby z niepełnosprawnościami ukazywane były jako wrogowie samych siebie, niemogący pogodzić się ze swoją sytuacja, niezdolni do samoakceptacji lub unikający leczenia i odtrącający pomoc ze strony otoczenia, skazując się na izolację w społeczeństwie. Przedstawiano je też jako ciężar dla osób sprawnych oraz zagrożenie dla społeczeństwa. W omawianym okresie niewiele przekazów ukazywało osoby niepełnosprawne jako normalnych ludzi uczestniczących w życiu społecznym. Zdaniem Barnesa obecne w przekazach masowych stereotypy ${ }^{1}$ osób niepełnosprawnych przyczyniały się do dyskryminacji i wykluczania tej kategorii z głównego nurtu życia społecznego (Barnes 1992: 39).

Zdaniem Melvina L. DeFleura i Everette'a M. Dennisa media masowe często ukazują portrety grup mniejszościowych jako posiadające więcej cech negatywnych niż pozytywnych. Obrazy te są podobne w różnych mediach, co dostarcza potwierdzenia ich trafności i powoduje, że odbiorcy zapamiętują je jako relatywnie trwałe schematy - stereotypowe reprezentacje - których używają w odniesieniu do osób zaliczanych do tych kategorii, niezależnie od ich właściwych cech (DeFleur, Dennis 1996: 41-49).

Współczesne badania obrazów niepełnosprawności $\mathrm{w}$ polskich mediach również pokazują, że w Polsce do niedawna dominowały dwa skrajne sposoby kreowania wizerunku osoby niepełnosprawnej. Albo jest to osoba nieradząca sobie $w$ życiu, potrzebująca pomocy, albo heros - dzielnie walczący z własną niepełnosprawnością i nieprzychylnym otoczeniem (Ruść 2007). Brakuje natomiast pokazywania osób niepełnosprawnych jako zwykłych członków społeczeństwa, wypełniających role społeczne i realizujących aktywności takie same jak osoby sprawne w tym samym wieku i o podobnej pozycji społecznej. Utrwalało to stereotyp osoby niepełnosprawnej jako „innej”, wiodącej alternatywne życie, mającej odmienne problemy niż reszta społeczeństwa (Struck-Peregończyk 2013).

${ }^{1}$ Stereotyp rozumiany tu jest jako trwałe i odporne na zmiane systemy uproszczonych przekonań członków jednej grupy systemy uproszczonych przekonan członkow jednej grupy
o członkach innej, „obcej” grupy, mający wyrażne konotacje o członkach innej, ,obcej" grupy, majacy wyrazne
emocjonalne i oceniające (por. Mudyń 2002: 119-120).
Od kilku lat mamy do czynienia ze zmianą sposobów prezentacji osób niepełnosprawnych w mediach masowych w naszym kraju. Wpisuje się to w obejmujący kraje kręgu cywilizacji zachodniej proces budowania nowego paradygmatu w podejściu do zjawiska niepełnosprawności. Wynika on ze wzrostu znaczenia doktryny praw człowieka jako podstawy ładu politycznego oraz stosunków społecznych i tym samym wymusza nowe spojrzenie na osoby niepełnosprawne i ich obecność w życiu społecznym (Ostrowska 2015: 39). W odpowiedzi na te zmiany pojawiło się $\mathrm{w}$ ostatnich latach $\mathrm{w}$ mediach więcej programów, filmów oraz wydawnictw dotyczących niepełnosprawności (Podgórska-Jachnik 2013: 66-67; Sahaj 2016: 110). Osoby z niepełnosprawnościami stały się bardziej widoczne w przekazach medialnych, a także coraz częściej są one przedstawiane $\mathrm{w}$ rolach nieoczywistych, wychodzących poza stereotypowe wyobrażenie ich pozycji, na przykład jako widz, kibic, zawodnik (Sahaj 2017: 185). Tym samym media masowe bardziej zaangażowały się w realizację misji społecznej polegającej na wywołaniu efektu ",oswojenia" z niepełnosprawnością w społeczeństwie (Podgórska-Jachnik 2013: 67). Taka obecność osób z dysfunkcjami w mediach może przyczyniać się do odczarowania sposobów postrzegania niepełnosprawności, mających swoje źródła w stereotypowych wyobrażeniach, które do niedawna były powszechnie obecne w tekstach kultury. Towarzyszy temu odejście od dychotomicznego przedstawiania osób niepełnosprawnych w kategoriach jednostki chorej, zależnej, potrzebującej pomocy i stawianej w opozycji do niezależnego herosa, pokonującego wszelkie trudności i osiągającego spektakularne sukcesy (Sahaj 2017: 184). W mediach coraz częściej pokazywane są osoby niepeł- nosprawne jako zwykli członkowie społeczeństwa, wypełniający role społeczne i realizujący aktywności takie same jak osoby sprawne, na przykład $\mathrm{w}$ filmach oraz serialach telewizyjnych. Pokazują one bowiem realne, a nie wyimaginowane problemy osób z deficytami sprawności. Osoby niepełnosprawne przedstawiane są w nich jako jednostki mające takie same potrzeby i problemy jak osoby sprawne, a jedyną różnicą są (częściowo) inne sposoby radzenia sobie z przeciwnościami i realizacji swoich pragnień (Sahaj 2013). Dużą rolę w tej przestrzeni odgrywają filmy fabularne, przedstawiające realistyczny obraz niepełnosprawności, w których obok bolączek i problemów związanych z dysfunkcjami ukazani są niepełnosprawni bohaterowie. Co ważne, zmagają się oni z naturalnymi ludzkimi potrzebami i pragnieniami, które mają uniwersalny charakter (Sahaj 2016: 139-153). W ten nurt wpisują się też programy rozrywkowe, takie jak "Masz Talent", „You Can Dance” czy „Must Be the Music”. Od wielu lat występują w nich osoby z różnymi rodzajami niepełnosprawności, które prezentują szerokiej widowni swoje rozwinięte umiejętności i to $\mathrm{w}$ najlepszym czasie antenowym. Przyczynia się to do zmiany stereotypowych wyobrażeń o niepełnosprawności i pozwala na oswojenie się sprawnej części widowni z potrzebami i stylami życia osób o odmiennych sprawnościach (Sahaj 2016: 136). Tym samym przekazy medialne mogą przyczyniać się do przełamywania istniejących uprzedzeń i stereotypów.

Te pozytywne tendencje nie oznaczają jednak, że $\mathrm{w}$ mediach nie występują już treści wyraźnie deprecjonujące osoby niepełnosprawne i wpisujące się $\mathrm{w}$ negatywne stereotypy. Wyniki analizy w zakresie 
prezentacji treści związanych z niepełnosprawnością prowadzone przez Krajową Radę Radiofonii i Telewizji pokazują, że w telewizji osoby niepełnosprawne ukazywane są często przez pryzmat swoich problemów, nieszczęść, barier, potrzeby niesienia im pomocy $\mathrm{i}$ interwencji $\mathrm{w}$ sprawie przepisów utrudniających sprawne funkcjonowanie (KRRiT 2014). Uświadamia nam to, że choć ujęcia niepełnosprawności ulegają zmianie we współczesnych mediach, to nadal obecne są $\mathrm{w}$ nich reprezentacje nacechowane negatywnie. $\mathrm{W}$ tym kontekście chcielibyśmy poszerzyć zakres zgromadzonej wiedzy o kolejne medium, które na przełomie XX i XXI wieku zyskało ogromną i stale rosnącą popularność.

Celem niniejszego artykułu jest sprawdzenie, czy nowe (masowe) medium cyfrowe, jakim są gry wideo $^{2}$, replikuje stereotypowe reprezentacje niepełnosprawności, typowe dla mediów XX wieku. Literatura przedmiotu nie dostarcza dostatecznych przykładów, więc uznać należy, że w przypadku gier cyfrowych zagadnienie to nie zostało dostatecznie rozpoznane. Dlatego też zrealizowaliśmy jakościowe badanie zawartości wybranych produkcji, wpisujące się w ideę badań eksploracyjnych (Babbie 2004: 111). Chcielibyśmy jednocześnie zaznaczyć, że podjęte przez nas przedsięwzięcie nie wyczerpuje obranej problematyki, a raczej mapuje ten obszar badawczy i określa kolejne możliwe ścieżki analiz. Dlatego przedstawiane w drugiej części artykułu wnioski powinny być traktowane jako punkt wyjścia dla dyskusji i kolejnych projektów, a nie ostateczne słowo $\mathrm{w}$ temacie reprezentacji niepet- nosprawności w grach elektronicznych. Już w tym miejscu warto podkreślić, że trudno tu o jednoznaczne interpretacje, co wynika także ze specyfiki omawianego medium, o czym szczegółowo piszemy w dalszej części artykułu.

\section{Luka badawcza: obrazy}

\section{niepełnosprawności w grach cyfrowych}

W badaniach nad zjawiskiem niepełnosprawności $\mathrm{w}$ odniesieniu do gier wideo brakuje refleksji dotyczących wizerunków postaci niepełnosprawnych.

Dotychczas prowadzone analizy mieściły się w trzech nurtach. Pierwszy dotyczył utrudnień $\mathrm{w}$ dostępności gier wideo dla niepełnosprawnych odbiorców. Badacze w swoich pracach koncentrowali się na identyfikacji barier, jakie tacy użytkownicy spotykają $\mathrm{w}$ grach oraz możliwościach ich wyeliminowania (Bierre i in. 2005; Atkinson i in. 2006; Grammenos 2008; Bei, Folmer, Harris 2011). Drugi obejmował ukazanie możliwości wykorzystania gier wideo $\mathrm{w}$ procesie rehabilitacji i wyrównywania deficytów osób z niepełnosprawnościami (por Sandlund, McDonough, Häger-Ross 2009; Alankus i in. 2010; Flynn, Lange 2010; Lange i in. 2010). Trzeci nurt koncentrował się na ukazaniu gier w szerokiej perspektywie związanej z funkcjami, jakie pełnią dla osób z niepełnosprawnościami (Walter 2011; Zielińska 2012; Gałuszka 2017). Wśród tych ujęć badawczych brakuje spojrzenia na gry wideo jak na media zdolne do utrwalenia lub zmiany stereotypowych wyobrażeń dotyczących niepełnosprawności. Podjęcie takiej analizy jest istotne, ponieważ obecnie odgrywają one coraz ważniejszą rolę we współczesnej kulturze, która ulega przemianom pod wpły- wem nowych technologii, co sprzyja procesom jej ludyfikacji. Zasadniczo proces ludyfikacji kultury polega na rosnącej roli zabawy w różnych kontekstach życia społecznego i w praktykach kulturowych (por. Dippel, Fizek 2017; Mäyrä 2017). Nowoczesne technologie zmieniają zarówno sposoby korzystania z mediów tradycyjnych, jak i tworzą coraz szerszy dostęp do rozrywek i gier cyfrowych. Na przykład urządzenia mobilne poszerzają dostępność gier dzięki odpowiednim aplikacjom, umożliwiając jednocześnie nawiązywanie interakcji z innymi użytkownikami w czasie rzeczywistym (por. Raessens 2010: 8). Prowadzi to do powstawania nowych form uczestnictwa w kulturze o ludycznym charakterze. Jednocześnie grywalizacja powoduje, że elementy gry przenikają do codziennej rzeczywistości, wywierając wpływ na zachowania ludzi niekoniecznie zainteresowanych grami (Zichermann, Linder: 2013), na przykład w firmach czy instytucjach, które zdecydowały się na wprowadzenie skwantyfikowanych (tzn. opartych na punktach) rankingów pracowniczych. Nie tylko w grze, ale również w rzeczywistości społecznej ludzie angażują się w zbieranie punktów, które gwarantują wygraną, co przekłada się na ich pozycję. Takie działania znane z gry przenikają do wielu dziedzin życia współczesnych społeczeństw, prowadząc do ich zmiany (por. Robertson 2010). Zjawiska te ulegają nasileniu w ostatnich latach, co sprawia, że gry wideo stają się dziś ważnym medium, w którym konstruowane są też warte omówienia obrazy niepełnosprawności. Tę wzrastającą doniosłość społeczną gier cyfrowych potwierdzają realizowane badania. Przykładowo w publikowanym od 2005 roku raporcie pod tytułem Essential Facts About the Computer and Video Game Industry przedstawiane są dane na temat populacji graczy w Stanach Zjednoczonych, czyli jednym z ważniejszych rynków dla branży elektronicznej rozrywki. W ostatniej edycji ujawniono, że w 65\% amerykańskich gospodarstw domowych żyje przynajmniej jedna osoba, która zadeklarowała sięganie po gry wideo $\mathrm{w}$ wymiarze $3 \mathrm{i}$ więcej godzin tygodniowo, a w $67 \%$ znajdują się sprzęty używane do grania (ESA 2017: 4). Co więcej, z wyliczeń autorów wynika, że średnia wieku amerykańskiego gracza to 35 lat (ESA 2017: 7), przy czym w roku 2005 było to 30 lat (ESA 2005: 2). Natomiast popularność sięgania po gry cyfrowe w Polsce opisuje publikowany od trzech lat raport Kondycja Polskiej Branży Gier, w którym liczba graczy jest ustalana $w$ odniesieniu do liczby internautów. W 2016 roku 68\% internautów w wieku 15-55 lat zagrało w grę wideo przynajmniej raz w ciągu ostatniego miesiąca (Bobrowski i in. 2017: 32). Widać więc, że sięganie po gry cyfrowe staje się popularną i masową formą spędzania czasu wolnego, a tym samym źródłem treści socjalizacyjnych, które mogą wpływać na światopogląd graczy. Już w roku 2004 Zbyszko Melosik pisał, że w przypadku ludzi młodych gry komputerowe stają się ważniejsze od tradycyjnych tekstów kultury, takich jak powszechnie uznawane za kanon polskiej literatury dzieła Bolesława Prusa czy Jana Kochanowskiego (Melosik 2004: 68). Uważamy więc, że gry elektroniczne, będące tak samo istotnym źródłem treści jak tradycyjne media, powinny doczekać się analiz pod kątem sposobów prezentowania postaci niepełnosprawnych.

\section{Obrazy niepełnosprawności w grach wideo - metoda badań}

Podstawowym celem opisywanego dalej badania było ukazanie najważniejszych sposobów reprezentacji niepełnosprawności w medium gier wideo. 
Dla zrealizowania założonego celu posłużyliśmy się jakościową analizą treści. Metoda ta pozwoliła na odtworzenie budowanych $w$ grach cyfrowych obrazów niepełnosprawności w oparciu o analizę ich zawartości, a w szczególności charakterystyk niepełnosprawnych bohaterów. Analiza ta wpisuje się w nurt badań koncentrujących się na odtworzeniu budowanych $\mathrm{w}$ ramach tego medium portretów określonych kategorii społecznych (Ivory 2013: 41). Prowadzone dotąd analizy oparte o ten rodzaj metodologii pozwoliły na zrekonstruowanie obecnych w grach wideo wizerunków płci. Umożliwiło to pokazanie, że sposoby ukazywania postaci (w tym wypadku kobiet i mężczyzn) w grach mogą mieć wpływ na postrzegania ról płciowych przez użytkowników (por. Dietz 1998; Martins i in. 2009). Dotychczas prowadzone projekty nie obejmowały sposobów prezentacji osób niepełnosprawnych, co uzasadnia podjęcie badań $\mathrm{w}$ tym zakresie.

Naszą analizę staraliśmy się oprzeć na przykładach gier popularnych, przy czym nie było to decydujące kryterium, ponieważ odwołujemy się także do produkcji niezależnych - często innowacyjnych pod względem formalnym czy fabularnym, ale zwykle produkowanych przez relatywnie niewielkie studia, które nie mają wystarczających środków do wydawania gier przynoszących zyski na poziomie największych komercyjnych produkcji (chociaż nie jest to bezwzględna zasada). Takie zestawienie okazało się być przydatne do pokazania potencjału tkwiącego w omawianym medium do ukazywania zjawiska niepełnosprawności. Potencjał ten bywa ograniczany przez założenia produkcji wysokobudżetowych - często wtórnych, reprodukujących dobrze znane i niekiedy wyczerpane wzorce i me- chaniki, ale przy tym docierających do szerokiego grona odbiorców. Punktem wyjścia był dla nas przegląd bazy gier wideo witryny Giantbomb.com pod kątem obecności postaci z niepełnosprawnościami lub różnego rodzaju ograniczeniami natury fizycznej bądź intelektualnej. Wspomniana baza zawiera ponad 57000 tytułów na różne platformy sprzęto$w^{3}$. Jej cechą szczególną jest powiązanie każdej skatalogowanej gry z różnymi kategoriami obiektów (ponad 6100 przedmiotów) i koncepcji (więcej niż 8200). Przykładami sklasyfikowanych obiektów, czyli zazwyczaj przedmiotów z gier wideo, są: lampa ścienna, satelita czy skrzynka na narzędzia. Z kolei bardziej ogólne koncepcje to między innymi: gry zremasterowane, ćwiczenia czy święta wojna. Z perspektywy podejmowanego w niniejszym tekście tematu przydatne okazało się odwołanie do przedmiotu, jakim jest wózek na kółkach oraz następujących kategorii: ślepota, upośledzenie słuchu, dysleksja, ślepota barw, okaleczony bohater, cukrzyca, zranienie, osłabiony ruch, oszpecenie, niepoczytalność oraz choroba. W efekcie udało nam się dotrzeć do 787 wyników odnoszących się zarówno do gier wideo, jak i występujących w nich postaci..

Taki dobór próby badawczej został podyktowany chęcią uchwycenia maksymalnej różnorodności przedstawianych postaci, a w konsekwencji szerokiego ukazania najważniejszych sposobów ich prezentacji w omawianym medium. Przedstawione poniżej wnioski prezentujemy w syntetycznej formie i w odniesieniu do przykładów, naszym zdaniem, najbardziej reprezentatywnych i poznawczo interesujących.

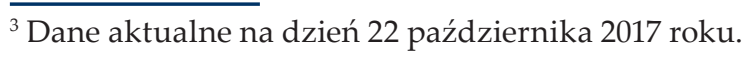

\section{Analiza obrazów niepełnosprawności $w$ wybranych grach wideo}

Zasadniczo należy wyróżnić dwa podstawowe sposoby ukazywania niepełnosprawności w grach cyfrowych jako cechy, która może dotyczyć postaci niezależnej (ang. NPC, non-player character) lub kontrolowanej przez gracza. Przy czym ten pierwszy jest zdecydowanie częściej spotykany w wysokobudżetowych grach komercyjnych, skierowanych do szerokiej grupy odbiorców, z kolei gry niezależne okazują się być bardziej różnorodne i awangardowe $\mathrm{w}$ prezentowaniu postaci z niepełnosprawnościami, częściej dając graczowi możliwość sterowania takim bohaterem. Dodatkowo udało nam się zidentyfikować trzy istotne rodzaje prezentowanych ograniczeń, które dotyczą: funkcji motorycznych, zmysłu wzroku oraz kondycji psychicznej bohaterów. Jednocześnie warto odnotować, że w przypadku gier cyfrowych znacznie trudniej o tak jednorodne wnioski jak w opisanych we wcześniejszych fragmentach badaniach nad zjawiskiem niepełnosprawności w mediach tradycyjnych. Jak to opisujemy dalej, niektóre z reprezentacji są jedynie pozornie stereotypowe, inne z kolei da się wpisać w znane już i upraszczające modele. Pamiętać jednak trzeba, że gry cyfrowe to medium wymuszające aktywny odbiór. Dlatego te gry, które pozwalają na dynamiczną interakcje pomiędzy graczem a wytwarzanym obrazem postaci z niepełnosprawnością (np. poprzez wchodzenie w jej rolę czy współpracę polegającą na działaniu w symulowanym świecie), zyskują dodatkowy performatywny wymiar, czego nie zapewniają media pasywne. Ten potencjalnie szerszy stopień oddziaływania gier na odbiorcę wynika z ich symulacyjnego charakteru, a także z wplątania graczy w działania (interakcje) i reprezentacje wynikające z reguł, które należy przyswoić w toku rozgrywki (por. Frasca 2003: 225; Bogost 2007: IX). Niestety $\mathrm{w}$ wielu grach twórcy ograniczają ten potencjał poprzez implementację postaci $\mathrm{z}$ niepełnosprawnościami, które pełnią jedynie role drugoplanowe bez wpływu na mechanikę rozgrywki.

Niepełnosprawność lub ograniczenia postaci niezależnych to takie rozwiązania, które wdrażane są głównie $\mathrm{w}$ warstwie audiowizualnej i często nie korelują z poziomem mechanik czy reguł gry, która jest produktem wielowarstwowym. Innymi słowy, obszar reguł (ang. rule-based space) pozostaje w izolacji od przestrzeni zmediatyzowanej (ang. mediated space) (por. Nitsche 2008: 15-16). W praktyce polega to na tym, że reguły gry - stanowiące zbiór matematycznych zasad określających sposób działania wszelkich jej elementów, takich jak fizyka, grafika, dźwięk czy sztuczna inteligencja - nie mają przełożenia na formy prezentacji świata (przestrzeni) oraz postaci i vice versa. Przykładami mogą być sposoby ukazania Barbary Gordon (znanej też jako Wyrocznia) w grze Batman: Arkham Knight (2015, RocksteadyStudios) czy też Lestera Cresta z Grand Theft Auto 5 (2013, Rockstar Games). Chociaż $\mathrm{w}$ przeszłości alter ego Barbary była superbohaterka Batgirl, to we wspomnianej grze porusza się ona na wózku, co jest wynikiem uszkodzenia rdzenia kręgowego. Podobnie Lester, który zazwyczaj jest prezentowany w pozycji siedzącej, a gdy się przemieszcza to z pomocą laski, ponieważ bliżej nieokreślona choroba mocno ogranicza jego sprawność motoryczną. Obie te niezależne postacie pełnią rolę drugoplanową i chociaż związane są z nimi pewne misje fabularne, ich obecność $w$ grach ograni- 
cza się do warstwy prezentacji, głównie w formie wspólnych rozmów z postacią kierowaną przez gracza. Nie ma tu istotnego elementu interaktywnego (czy lepiej ergodycznego), to znaczy w żadnym momencie nie można przejąć kontroli nad Barbarą czy Lesterem, a ich niepełnosprawność nie stanowi istotnego wątku, zarówno w wymiarze fabularnym (jedynie okazyjne nawiązania do ich stanu fizycznego), jak i rozgrywki (w obu produkcjach nie pojawiają się specyficzne mechaniki powiązane ze stanem fizycznym tych bohaterów). Gdyby Lester był postacią pełnosprawną, to zarówno uniwersum, jak i sposób rozgrywki w GTA 5 nie byłyby istotnie odmienne od stanu obecnego. Co więcej, w przypadku Wyroczni ujawnia się problem określany mianem damy w opałach (ang. damsel in distress), czyli jej uprzedmiotowienia i sprowadzenia do roli bezradnej i wymagającej pomocy ze strony silniejszego mężczyzny - w tej funkcji oczywiście Batman, który na pewnym (krótkim) etapie gry nie tylko odbija Wyrocznię z rąk głównego przeciwnika, ale też nosi ją na rękach i przewozi na bezpieczny dla niej komisariat policji. Mimo takiego przedstawienia wymienieni bohaterowie w pisują się w model osoby raczej zaradnej życiowo i przełamującej własne ograniczenia (Lester często wstaje z wózka i angażuje się w skomplikowane akcje przestępcze prezentowane w GTA 5) czy świetnie odnajdującej się w nowej roli (Wyrocznia nieustannie wspiera Batmana w jego działaniach dzięki swoim niezwykłym umiejętnościom hakerskim). Nie ma tu jednak mowy o pełnym wykorzystaniu potencjału gier elektronicznych w ukazywaniu postaci z dysfunkcjami.

Nieco inaczej omawiane zagadnienie wygląda w przypadku gier, których autorzy zastosowali szerszy wachlarz możliwych do wykonania akcji względem bohaterów z niepełnosprawnościami. Pośrednim przykładem może być niezależna postać Agathy, która występuje w przygodowej grze Fahrenheit: IndigoProphecy (2005, QuanticDream). $\mathrm{W}$ jednej z misji główny bohater sterowany przez gracza musi udać się na spotkanie z tą kobietą - niewidomą i siedzącą na wózku staruszką, będącą jednocześnie medium z niezwykłymi wizjami. Scena ta jest kluczowa dla fabuły, jednak inaczej niż w przypadku dwóch poprzednich produkcji pojawia się tutaj interesujący fragment rozgrywki, podczas którego gracz pcha wózek ze staruszką. Analogia do opisanego wcześniej przykładu Barbary Gordon jest jednak pozorna, ponieważ krótki segment, kiedy gracz - kontrolując Batmana - przenosi Barbarę jest pozbawiony jej wyraźnej prośby oraz atrybutów wskazujących na jej stan fizyczny. $\mathrm{W}$ zasadzie scena ta przywodzi na myśl generyczny zabieg uwolnienia $\mathrm{z}$ opresji bezbronnej kobiety, tak dobrze znany z wielu popkulturowych obrazów, przez co zagadnienie niepełnosprawności schodzi na dalszy plan. Natomiast w Fahrenheit graczowi przedstawia się kilka dodatkowych atrybutów, które jednak wpisują się w stereotypowe wyobrażenie niepełnosprawnego seniora: wózek na kółkach, powiązane ze sobą choroby (niedowład kończyn dolnych, ślepota), osamotnienie i dziwne zwyczaje (Agatha mieszka sama, otaczając się zarówno żywymi, jak i wypchanymi ptakami). Przy czym to stereotypowe ujęcie częściowo przełamują zarówno paranormalne - tudzież magiczne, nadludzkie - zdolności bohaterki, jak i niektóre jej zachowania, co jest typowym dla wielu gier zabiegiem, poprzez który uzasadnia się obecność bohatera w uniwersum gry. Tu konkretnie mamy do czy- nienia z medium, które przez swoje wizje spełnia bardzo istotną funkcję fabularną. Co więcej, te zdolności staruszki pozwalają jej przełamać ograniczenia fizyczne, ponieważ $\mathrm{w}$ jednym przerywniku filmowym karci ona postać kierowaną przez gracza, kiedy ta "potwierdza” fakt, że Agatha jest niewidoma poprzez machanie ręką przed jej twarzą (wyczuwając ten akt w bliżej niewyjaśniony i pozazmysłowy sposób), a następnie wydaje polecenie przewiezienia do sąsiedniego pokoju, co jest już realizowane bezpośrednio przez gracza. Mamy tu przykład nie tylko nadania osobie niepełnosprawnej dodatkowych kompetencji i pewnego zakresu podmiotowości, ale też postawienie odbiorcy $\mathrm{w}$ roli bezpośrednio wspierającej (pchającej wózek) dzięki powiązaniu sceny filmowej (obszar reprezentacji) z mechaniką rozgrywki (obszar reguł). W efekcie odbiorca może nie tylko obserwować funkcjonowanie osoby na wózku (jak w filmie), ale też na chwilę niejako zaangażować się w jej życie. Jeszcze dalej idą twórcy wysokobudżetowego Mass Effect 2 (2010, BioWare), ponieważ $\mathrm{w}$ jednej z misji pozwalają graczowi przejąć kontrolę nad cierpiącym na wrodzoną łamliwość kości Jeffem ,JJokerem” Moreau. Jeff to kolejna w zestawieniu niezależna postać drugoplanowa. Utalentowany pilot wojskowy - występujący w trzech pierwszych grach z serii Mass Effect - który $\mathrm{w}$ zasadzie nie opuszcza swojego stanowiska, ponieważ chodzenie sprawia mu wyjątkową trudność. Jednak w drugiej części gry udostępniono fragment jednej z misji, podczas którego przejmujemy nad nim kontrolę na zaatakowanym przez wrogów statku kosmicznym Normandia. W tej misji zadaniem gracza jest przemieszczanie się oraz unikanie niebezpiecznych kosmitów. Moreau nie jest uzbrojony, ale z pomocą pokładowej sztucznej inteligencji jest w stanie przechytrzyć znacznie sprawniejszych fizycznie przeciwników i uratować statek. Chociaż sterowana postać nie może biegać, wyraźnie kuleje i przyjmuje skrzywioną postawę (czyli jest wiarygodnie przedstawiona $\mathrm{w}$ warstwie reprezentacji), ostatecznie wygrywa w tej nierównej rywalizacji. W ten sposób twórcy podkreślili sprawczość tego bohatera, jego kompetencje i odwagę, a jednocześnie zachowali spójność wszystkich elementów gry - fabuły, charakterystyki bohatera i rozgrywki. Wpływa to nie tylko na koherentność świata przedstawionego, ale też ogranicza zjawisko dysonansu ludonarracyjnego, czyli sprzeczności, jaka może zachodzić pomiędzy estetyka, systemem narracji i regułami danej gry (por. Hocking 2007). Podobnie rzecz się ma $\mathrm{w}$ początkowych misjach $\mathrm{z}$ gry Wolfenstein 2: The New Colossus (2017, Bethesda Softworks), podczas których gracz kontroluje siedzącego na wózku Williama „B.J.” Blazkowicza walczącego z nazistami żołnierza o polsko-żydowskich korzeniach. Blazkowicz traci swoją sprawność w wyniku wydarzeń z poprzedniej części gry. Zmienia się z efektownego i efektywnego egzekutora w wyszydzaną przez nazistowskich wrogów „,kalekę". Wydaje się jednak, że autorzy gry świadomie i celowo odwołali się do zjawiska niepełnosprawności, implementując szereg rozwiązań $\mathrm{w}$ warstwie reguł. Ich bohater na wózku ma istotne ograniczenia i odczuwa je sam gracz, więc jego doświadczenie staje się niejako doświadczeniem osoby posadzonej na wózku. Przykładowo nie może poruszać się w sposób właściwy dla pełnosprawnych postaci - na przykład wjeżdżać po schodach, podskakiwać (dostępna jest jedynie namiastka skoku) czy wspinać się po drabinach. Ma tylko jedną broń, chociaż do tej pory mógł jednocześnie 
dzierżyć dwa karabiny, a jego statystyki zdrowia są obniżone do połowy wartości bazowych. Dodatkowo widać też, że projekt poziomu (wielka łódź wojskowa) został przygotowany w sposób umożliwiający poruszanie się na wózku: nie brakuje podjazdów, wind i taśmociągów uruchamianych na przycisk. Za inny warty przytoczenia przykład odpowiadają autorzy cenionej - między innymi za twórczą reinterpretację klasycznej historii Czerwonego Kapturka, nowatorskie rozwiązania $\mathrm{w}$ zakresie eksploracji przestrzeni i nieliniowej rozgrywki - gry niezależnej The Path (2009, Tale of Tales). Sama produkcja jest przepełnionym symboliką horrorem, historią pieszej podróży z miasta do leśnej chatki babci, którą można przebyć każdą z sześciu możliwych do wyboru bohaterek. Jedną z nich jest 15-letnia Ruby. Chociaż dziewczyna nosi ortezę na lewej nodze, to jej ruchy są tak samo sprawne jak pozostałych dostępnych postaci, co więcej może ona biegać szybciej niż jej siostry. To zaskakujący zabieg, ale wydaje się celowy. Twórcy w ten sposób uciekają od oczywistej interpretacji stanu bohaterki, przy czym nie pozwalają zapomnieć o kwestii niepełnosprawności, chociażby poprzez scenę z leśnego traktu, w której Ruby znajduje wózek na kółkach, będący istotnym przedmiotem w biografii tej postaci. The Path nie jest grą z jasno ustalonym celem czy jedną ścieżką postępowania, która prowadzi do zwycięstwa. Sporo w niej niedomówień, symbolizmu, alegorii czy onirycznych wizji. Taki projekt gry, połączony z nieoczywistym zachowaniem niby niepełnosprawnej bohaterki, która w rzeczywistości okazuje się - przynajmniej fizycznie - sprawna, ale jednocześnie skrywa w sobie jakąś traumę, stawiają gracza przed koniecznością snucia domysłów i kreowania własnych interpretacji. Niektóre z nich mogą prowadzić do opisywanego dystansu ludonarracyj- nego, inne wręcz przeciwnie, na przykład potraktowanie ortezy nie jako narzędzia medycznego, a jako podkreślający osobowość bohaterki element stroju. Niestety, niewiele gier pozwala na taką swobodę i zarazem głębię interpretacyjna, szczególnie w odniesieniu do omawianej tu problematyki. Natomiast $\mathrm{z}$ dystansem ludonarracyjnym nie poradzili sobie twórcy z firmy Neversoft Entertainment, którzy stworzyli grywalną postać Pauliego „Wheels Of Fury" Ryana. Paulie to siedzący na wózku nastolatek, który pojawił się w popularnej grze traktującej o skateboardingu Tony Hawk's Underground 2 (2004, Activision). Takie połączenie wydaje się dość zaskakujące, ale w praktyce niepełnosprawność Pauliego $\mathrm{w}$ większym stopniu ujawnia się $\mathrm{w}$ przerywnikach filmowych niż w faktycznej rozgrywce, gdyż postać ta nie zachowuje się w sposób istotnie różny od dostępnych w grze pełnosprawnych skaterów. Owszem, różnice pojawiają się na poziomie nominalnym, czego przykładem mogą być inne nazwy wykonywanych sztuczek (w ich opisach zamiast deskorolki jest wózek na kółkach), ale na tym w zasadzie kończy się inwencja autorów w odniesieniu do omawianej postaci. Paulie równie skutecznie wykonuje niesamowite akrobacje, polegające między innymi na skakaniu po budynkach czy bardzo wysokich rampach, co może być odebrane jako próba zrównania potencjału wszystkich bohaterów - bez względu na ich stan fizyczny. Takie równościowe podejście i podkreślenie zaradności niepełnosprawnego chłopca może z jednej strony budzić słuszne zadowolenie, (szczególnie jeżeli było celowe i świadome zaimplementowane przez autorów gry), ale jednocześnie naraża odbiorców na możliwość zaistnienia poczucia dysonansu ludonarracyjnego.
W dotychczas przedstawionych przykładach nawiązaliśmy do postaci z ograniczeniami ruchowymi i nie jest to przypadek. Bohaterzy kulejący, utykający, wspierający się laskami czy rzadziej na wózkach to zdaje się najbardziej powszechne reprezentacje ograniczonej sprawności postaci $\mathrm{w}$ grach wideo zarówno $\mathrm{w}$ popularnych produkcjach wysokobudżetowych, jak i mniejszych grach niezależnych. Oczywiście zdecydowanie częściej chodzi o niezależnych bohaterów drugoplanowych - szczególnie w przypadku poważniejszych ograniczeń, związanych z poruszaniem się na wózku. Próby wkładania graczy w rolę takiego głównego bohatera są rzadkie w grach komercyjnych. Podobnie wygląda ta kwestia $\mathrm{w}$ odniesieniu do drugiej popularnej kategorii, jaką są bohaterzy niewidomi. Przykładami takich postaci mogą być - poza opisywaną wcześniej Agathą - Theresa z serii Fable (2004-2010, Microsoft Studios) czy Kenshi Takahashi z gier z serii Mortal Combat (1992-2016, Warner Bros.). Ta pierwsza to ważna postać niezależna (kontrolowana przez komputer), ten drugi jest $\mathrm{z}$ kolei możliwym do wyboru (kontrolowanym przez gracza) wojownikiem. Pomimo tej istotnej różnicy $\mathrm{w}$ obu przypadkach niepełnosprawność bohaterów ogranicza się w zasadzie tylko do warstwy fabularnej oraz reprezentacji i nie ma przełożenia na faktyczną rozgrywkę. Gracz poznaje genezę ich niepełnosprawności, dostrzega zewnętrzne jej atrybuty (np. opaska na oczach), ale jednocześnie pozwala mu się rywalizować z tymi bohaterami - lub ich kontrolować - jakby byli zupełnie pełnosprawni. To dominujacy model, ale czy tak musi być? Niekoniecznie, co pokazali twórcy niezależnego The Path. Zasadniczo w wysokobudżetowych grach AAA (tzw. Triple-A, czyli produkcje o największych budżetach, z rozbu- dowaną promocją, cechujące się zazwyczaj wysoką jakością, ale też powiązane z wysokimi oczekiwaniami sprzedażowymi) trudno oczekiwać innowacji w zakresie mechaniki i sposobów przedstawiania postaci, jednak pewne interesujące próby zostały powzięte, na przykład w popularnej grze akcji Metal Gear Solid 3: Snake Eater (2004, Konami). W tej produkcji przez krótki moment (tj. kilka sekund) widoczny na ekranie obraz jest częściowo zacieniony, ponieważ główny bohater traci oko w wyniku tortur. Niestety jest to segment gry, podczas którego wyświetlany jest film przerywnikowy, czyli wszystko ogranicza się do warstwy wizualnej, a do tego sam efekt trwa bardzo krótko. Dalej poszli twórcy gier niezależnych, takich jak Beyond Eyes (2015, Tiger and Squid), Perception (2017, The Deep End Games) czy The Blind Wizard of Antreia (w produkcji, Veare). W dwóch pierwszych główne bohaterki są niewidome, a mechanika rozgrywki oparta została na stopniowym odkrywaniu wirtualnej przestrzeni, którą początkowo spowija mrok, a istotne stają się inne zmysły, zasadniczo słuch. Oczywiście nie następuje tu przełamanie właściwej dla gier cyfrowych hegemonii wizualności (stanowiącej bardzo poważną przeszkodę w pełnym ukazywaniu grywalnych postaci niewidomych), ponieważ wciąż obszar wokół bohaterek jest - przynajmniej częściowo - widoczny i dostępny dla gracza, jednak sposób eksploracji w obu grach jest mocno nietypowy jak na standardy tego medium. Przedmioty i obiekty często są niewidoczne lub ograniczone do konturów, a nawigowanie $\mathrm{w}$ symulowanej przestrzeni trójwymiarowej rozpoczyna się od określenia źródeł dźwięków. Jest to zasadniczo odwrotna strategia do dominującej i rzeczywiście koresponduje ona z doświadczeniami osób niewidomych, co może 
pomagać widzącym użytkownikom w lepszym zrozumieniu rzeczywistości i potrzeb niewidzących. Inną drogą poszli twórcy The Blind Wizard of Antreia. To będąca w ciągłej produkcji polska powieść wizualna (ang. visual novel), która jest skierowanej głównie do osób niewidomych. Wybór takiej grupy docelowej zdefiniował założenia tego projektu, ponieważ manipulowanie w przestrzeni gry musi odbywać się tylko przy wykorzystaniu słuchu. Dlatego w tej produkcji praktycznie nie występuje grafika, a kluczowe są opisy czytane przez lektora i szczegółowe efekty dźwiękowe, których jakość pozwala na nawigowanie $\mathrm{w}$ oparciu o kierunek, z którego dochodzą. O tym tytule wspominamy na marginesie naszych rozważań, by nakreślić zakres możliwych do wdrożenia mechanizmów rozgrywki, których jednak próżno doszukiwać się w grach projektowanych z myślą o przeciętnym - to znaczy pełnosprawnym - odbiorcy ${ }^{4}$. W takich produkcjach istotną rolę odgrywa aspekt wizualny i możliwość manipulowania $\mathrm{w}$ przestrzeni (dwuwymiarowej czy trójwymiarowej). Oczywiście The Blind Wizard of Antreia może być wykorzystywane przez osoby widzące - wystarczy założyć opaskę na oczy - jednak dla takich graczy produkcja ta stanowić będzie raczej mniej lub bardziej interesującą ciekawostkę. Dodatkowo brak wsparcia dużego wydawcy i ukierunkowanie na specyficzną grupę odbiorców prawdopodobnie skutecznie ograniczą możliwość dotarcia do większej liczby pełnosprawnych graczy, którzy mogliby poprzez ten tytuł „poczuć się” jak niewidomy fan gier wideo, a przez to lepiej zrozumieć potrzeby osób o ograniczonej sprawności widzenia.
Ostatnim wyodrębnionym przez nas obrazem niepełnosprawności w grach cyfrowych są reprezentacje ukazujące ograniczenia wynikające z kondycji intelektualnej lub psychicznej bohaterów. Podobnie jak w przypadku dwóch poprzednich form i tutaj dominują postacie niezależne, przedstawiane głównie $\mathrm{w}$ warstwie narracyjnej i wizualnej, ale inacze niż $\mathrm{w}$ odniesieniu do niewidomych nie zachodzi tu podstawowa trudność związana z audiowizualnym charakterem gier elektronicznych. Okazuje się, że objawy choroby psychicznej da się w relatywnie prosty sposób przedstawiać - zarówno na poziomie narracyjnym (poprzez odpowiednią biografię postaci), jak i wizualnym (np. pokazując szaleńcze wizje, omamy czy autystyczne lub destrukcyjne zachowania). Przy czym należy podkreślić, że często $\mathrm{w}$ grach brakuje pogłębionego objaśnienia stanu psychologicznego i emocjonalnego bohaterów, szczególnie tych drugoplanowych. Zazwyczaj chodzi o bardzo ogólnie rozumiane szaleństwo, które oczywiście nie jest jednostką chorobową, a kategorią wskazującą na odbiegające od normy zachowania postaci, takie jak: niekontrolowane i gwałtowne reakcje, wyjątkowa brutalność, halucynacje, lęki czy manie. W bazie witryny Giantbomb.com znaleźć można 347 postaci i gier wideo odnoszących się do omawianego pojęcia, przy czym obserwuje się tu znaczną rozpiętość znaczeń. Przykładowo postacią sklasyfikowaną jako szalona jest NPC Col Kalom - przywódca sekty, występujący w popularnej grze fabularnej Gothic (2001, PiranhaBytes), który w pewnym momencie uświadamia sobie, że wyznawane przez niego bóstwo jest $\mathrm{w}$ istocie zagrażającym światu demonem, po czym decyduje się na szaleńczą misję uwolnienia stwora, co ostatecznie sprowadza na niego śmierć $\mathrm{z}$ rąk protagonisty kontrolowanego przez gracza. Jednocześnie w omawianej kategorii bazy Giantbomb.com znalazł się Max Payne - nowojorski policjant, główny bohater głośnej gry akcji pod tym samym tytułem, którego spotyka ogromna osobista tragedia. Jego rodzina zostaje zamordowana, a on nie jest $\mathrm{w}$ stanie temu zaradzić. W efekcie w jednej z misji nawiedzają go obłędne wizje z miejsca morderstwa, podczas których gracz musi nawigować w mrocznej i osadzonej w konwencji onirycznej przestrzeni, przeszywanej krzykami zamordowanej żony Maxa i płaczem ich dziecka. Oczywiście ta sytuacja jest tymczasowa, ponieważ przez większą część gry Max zachowuje stabilność psychiczną. Inaczej jest w przypadku Vaasa Montenegro, bodaj najbardziej ikonicznego "psychopaty”, który pojawił się w grze akcji Far Cry 3 (2012, Ubisoft). Jako główny antagonista - impulsywny, sadystyczny, niestabilny psychicznie - był on często pokazywany i promowany $\mathrm{w}$ oficjalnych materiałach marketingowych, a także wielokrotnie pojawiał się $\mathrm{w}$ grze podczas filmowych scen przerywnikowych. W przypadku Vaasa poziom dysfunkcji jest stały, chociaż ukazany z perspektywy zewnętrznego obserwatora, którym jest kontrolowany przez gracza główny bohater Far Cry 3. Natomiast szaleńcze wizje Maxa odzwierciedlają stan jego umysłu.

Przedstawione tu przykłady - podobnie jak wiele innych postaci, często występujących także poza światem gier wideo, na przykład Joker z uniwersum Batmana - odwołują się do kategorii, których zwyczajowo nie kojarzymy z niepełnosprawnością. Wspominamy jednak o nich, by nakreślić właściwą perspektywę. Rzeczywiście jest tak, że w grach wideo chętnie wykorzystuje się figurę szaleńca, by w łatwy sposób uzasadnić negatywne motywacje przeciwników (inną figurą może być zaraza, choroba, wpływ magicznych mocy) i dać graczowi powód do walki z nimi. Jednocześnie bardzo rzadko pojawiają się próby głębszego ujęcia zaburzeń rozwoju czy funkcjonowania intelektualnego. Nielicznymi przykładami mogą być Jade ze wspomnianego już Fahrenheit oraz Amy z gry o tym samym tytule. Obie cierpią na autyzm. Są zamknięte w sobie, małomówne, oderwane od rzeczywistości i zdane na łaskę dorosłych opiekunów. Chociaż rola Jade jest kluczowa dla uniwersum (jest ona wcieleniem zapowiadanego $\mathrm{w}$ proroctwach dziecka indygo, od którego zależy los świata i ludzkości), to $\mathrm{w}$ warstwie rozgrywki sprowadza się to do ciągłej opieki nad dziewczynką. Gracz musi ją przenosić rękoma kontrolowanych bohaterów, chronić przed atakami wrogów, a w ostatecznej misji zdecydować o jej losie. W grze brakuje nawet dialogów z dzieckiem, chociaż jest ono często eksponowane, na przykład jego pozbawiona emocji twarz. Bardziej rozbudowaną koncepcję zaprezentowali twórcy gry Amy (2012, VectorCell). Co prawda Amy, podobnie jak Jade, nie mówi, a także często poddaje się emocjom (np. czuje się przerażona, co widać w jej mimice twarzy, westchnieniach czy krzykach), jednak przy całej swojej bezradności wobec środowiska (akcja gry toczy się w katastroficznym świecie opanowanym przez zombie) jest też zdolna do pomocy swojej dorosłej opiekunce Lanie - kontrolowanej przez gracza. Przykładowo w jednej ze scen dziewczynka przeciska się przez wąski otwór wentylacyjny, by następnie wcisnać przycisk znajdujący się $\mathrm{w}$ zamkniętym pomieszczeniu, co otwiera przejście do dalszego etapu gry. $\mathrm{W}$ innym momencie przejawia ona zdolności informatyczne, łamiąc zabezpieczenia 
terminala zablokowanych drzwi, czy wykorzystuje swoje paranormalne moce do zatrzymania groźnego przeciwnika - co robi sam gracz, przejmując tymczasowo kontrolę nad małą bohaterką. W przedstawionych tu przykładach znów ujawnia się potencjał gier cyfrowych do interaktywnego przedstawiania postaci z niepełnosprawnościami. Dwie bardzo podobne bohaterki mogą być zarówno ubezwłasnowolnionym "przedmiotem” (Fahrenheit), jak i partnerem interakcyjnym (Amy). W tym drugim przypadku podkreślane są podmiotowość i sprawczość postaci autystycznej, a także jej potencjał do działania i podejmowania się interesujących czy niebezpiecznych zadań. Co więcej, gry wideo zdążyły już podjąć w sposób pogłębiony i interaktywny wątki zaburzeń psychicznych, chociażby depresji, ale znów chodzi tu o tytuły niszowe, takie jak niezależne Depression Quest (2013, Zoë Quinn), The Cat Lady (2012, Harvester Games) czy Indygo (2017, Pigmentum Game Studio). Do większego grona odbiorców trafić może głośna Hellblade: Senua's Sacrifice (2017, Ninja Theory), która została określona przez twórców mianem „niezależnej produkcji klasy AAA" (Dom 2014). W praktyce oznacza to, że model produkcji i dystrybucji tego produktu przypomina przedsięwzięcie realizowane przez niewielkie studio deweloperskie, ale jednocześnie sam projekt gry został przygotowany zgodnie $\mathrm{z}$ najwyższymi standardami typowymi dla produkcji wysokobudżetowych. W efekcie oprawa audiowizualna jest bardzo dobra, co osiągnięto między innymi dzięki technologiom przechwytywania ruchu i mapowania twarzy prawdziwej aktorki. W efekcie główna bohaterka cechuje się wysokiej jakości mimiką twarzy i szerokim wachlarzem emocji wyrażanych w komunikatach werbalnych i niewerbalnych.
Jednak tym, co sprawia, że warto poświęcić tej produkcji kilka zdań, jest powiązanie charakterystyki świata przedstawionego ze stanem psychicznym głównej postaci - celtyckiej wojowniczki o imieniu Senua. Jak wielokrotnie powtarzali autorzy, przedstawiony świat i podejmowane $\mathrm{w}$ nim akcje stanowią wizje cierpiącej na psychozę bohaterki, która jest efektem osobistej traumy (m.in. morderstwa ukochanego, który ginie podczas najazdu wikingów). Wydarzenia z gry stają się swoistą podróżą w głąb umysłu Seuny, pełnego zaburzeń świadomości, chaotycznych myśli, ciągle słyszanych głosów i szeptów, a także mniej lub bardziej przerażających halucynacji. Imponować może z jednej strony sposób przygotowania tych wszystkich elementów, a z drugiej powiązanie ich z mechaniką rozgrywki. Twórcy zadbali o wiarygodność pokazywanych w grze objawów choroby psychicznej poprzez konsultacje z ekspertami, odwołanie się do doświadczeń chorych, a także współpracę z naukowcami czy organizacjami zajmującymi się dobrostanem psychicznym $^{5}$. Cały ten kolektywny wysiłek znalazł swoje odzwierciedlenie $w$ mechanizmach rozgrywki. Przykładowo szepty i głosy są źródłem podpowiedzi dla gracza, a także informacji fabularnych i o świecie, a halucynacje stanowią istotne wskazówki wizualne, niezbędne do rozwiązywania zagadek graficznych, bez których nie można przejść do kolejnego etapu gry. Następuje tu ciekawe poszerzenie perspektywy na objawy i konsekwencje poważnej choroby, które nie są jedynie źródłem

${ }^{5}$ Interesujaccym aspektem tej wspótpracy jest specjalna strona dostępna pod adresem www.hellbladehelp.info. Została on przygotowana dla wszystkich osobbl ktore poczuły się w jakis
sposób dotknięte ukazanymi w Hellblade zjawiskami. Witryn zawiera dane kontaktowe do wybranych organizacji zajmujazawiera dane kontaktowe do wybranych organizacji zajmuja-
cych sie kwestiami zdrowia psychicznego. W przypadku Polski jest to Fundacja Polski Instytut Otwartego Dialogu. (pokazanego na przykładzie Seuny!) cierpienia, ale też elementem poszerzającym świat przedstawiony i potencjał poznawczy bohaterki. Tak więc Hellblade jest dobrze zrealizowanym produktem, który nie tylko bawi odbiorców, ale też daje im szansę bliższego poznania i zrozumienia niektórych problemów, z jakimi borykają się ludzie cierpiący na pewne choroby psychiczne. To dodatkowa wartość, związana stricte ze specyfiką interaktywnego medium, jakim są gry cyfrowe. Niestety w produkcjach wysokobudżetowych, skierowanych do masowego odbiorcy - czyli z największym potencjałem kształtowania społecznych postaw względem niepełnosprawności - ta problematyka pokazywana jest zazwyczaj w sposób uproszczony lub zupełnie się jej unika. Być może kolejne lata i kolejne sukcesy takich produkcji jak Hellblade przekonają decydentów w największych firmach do bardziej ambitnych i nieoczywistych rozwiązań.

\section{Wnioski i podsumowanie}

Gry wideo pozostają w procesie ciągłego i wielotorowego rozwoju, co utrudnia formułowanie zasadniczych wniosków dotyczących tego medium. Jednym z problematycznych zagadnień jest podjęta w niniejszym tekście problematyka reprezentacji niepełnosprawności. Gdyby podejść do tego w sposób czysto ilościowy, to konstatacja byłaby jednoznaczna: gry cyfrowe ciągle nie osiągnęły zadowalającego poziomu różnorodności prezentowanych bohaterów i podejmowanych zagadnień, w tym odnoszących się do zjawiska niepełnosprawności. To jest generalny problem tego medium i brakuje w nim nie tylko dobrze zaprojektowanych i przedstawionych bohaterów z różnego rodzaju ograni- czeniami fizyczno-mentalnymi, ale też ciekawych postaci kobiecych, przedstawicieli mniejszości rasowych czy seksualnych. Jednak bliższe zapoznanie się z tematem ujawnia przed nami spory potencjał gier $\mathrm{w}$ interesującym ujmowaniu zjawiska niepełnosprawności. Przy czym tu znów potrzeba kilku zastrzeżeń. Okazuje się, że charakterystyka omawianego medium ułatwia prezentowanie pewnego rodzaju schorzeń przy jednoczesnym dyskryminowaniu innych. $Z$ naszej analizy wynika, że ukazywanie niepełnosprawności powstałych $z$ upośledzenia narządów ruchu jest relatywnie powszechne i proste do wdrożenia - przynajmniej na poziomie zmediatyzowanym. Dużo trudniej wdrażać do gier postacie niesłyszące, niewidome czy cierpiące na zaburzenia rozwoju lub choroby psychiczne, szczególnie jeżeli mają to być bohaterowie kontrolowani przez gracza. Jeśli pominiemy specjalistyczne i niszowe gry zaprojektowane z myślą o osobach z konkretnymi dysfunkcjami (np. niewidomi), to okaże się, że na rynku jest bardzo niewiele produkcji, które pozwalają wejść w takie role. Oczywiście lepiej to wygląda, jeśli weźmiemy pod uwagę także te tytuły, w których obecność postaci z różnymi niepełnosprawnościami ogranicza się do warstwy narracyjnej czy audiowizualnej. Wtedy - wzorem starszych mediów, na przykład telewizji - jedynie pokazuje się daną postać $\mathrm{i}$ ewentualnie wiąże $\mathrm{z}$ nią wybrane misje czy historie, co jednak nie wykorzystuje opisanego wcześniej potencjału gier wideo. Ostateczną ocenę utrudnia kwestia (niekiedy pozornych) stereotypizacji niektórych growych bohaterów z niepełnosprawnościami. Tu znów decydująca okazuje się specyfika gier cyfrowych, a także procesów ich tworzenia i dystrybucji. Chodzi o to, że jest to medium, w którym z definicji postacie - główne oraz 
te ważne dla fabuły - przełamują wiele norm i zwyczajów czy są jednostkami wyjątkowymi, bo inaczej ich obecność w uniwersum i znaczenie w przedstawianej historii nie byłyby dostatecznie uzasadnione. Tu nasuwa się analogia do omawianego wcześniej katalogu obrazów niepełnosprawności Leonarda Kriegela czy też Colina Barnesa. Zarówno postawa „super" niepełnosprawnego tego pierwszego czy „super" kaleki drugiego dobrze opisuje wiele postaci growych o ograniczonej sprawności. Są to niekiedy jednostki przełamujące granice niedostępne nawet dla osób sprawnych. Ta uwaga w większym stopniu dotyczy postaci kierowanych przez gracza niż niezależnych, bo to główny bohater ma częściej za zadanie zrobić coś niezwykłego, na przykład uratować świat czy pokonać znacznie liczniejszych i silniejszych wrogów. Widać to w przedstawionych przez nas przykładach. Paulie to nastolatek na wózku, który nie ustępuje pełnosprawnym skaterom, Jeff jest jednym z najlepszych pilotów w elitarnej jednostce wojskowej (co w „realnym” życiu nie mogłoby mieć miejsca z racji jego ograniczeń motorycznych), niewidomy Kenshi Takahashi to potężny wojownik tak samo kompetentny jak widzacy przeciwnicy, autystyczna Amy przejawia niezwykłe zdolności (np. hackowania) i aktywnie wspiera swoją dorosłą opiekunkę w wysoce niesprzyjającym środowisku, a Senua równie dzielnie walczy z piekielnymi przeciwnikami co z objawami własnej psychozy. Wydaje się, że takie przedstawienia bohaterów z niepełnosprawnościami sprzyjaja ich upodmiotowieniu, mogą przełamywać stereotypy i przeciwdziałać dyskryminacji, a także działać na rzecz lepszego zrozumienia sytuacji osób niepełnosprawnych dzięki możliwości przynajmniej częściowego wejścia w ich sytuację życiową. Jednocześnie trudno tu o odwzorowania niepełnosprawności wpisujące się typowe (także dla osób pełnosprawnych) praktyki życia codziennego, ponieważ w grach elektronicznych taka perspektywa jest rzadkością. Gry wideo rzadko ukazują codzienność ${ }^{\mathrm{W}} \mathrm{w}$ formie, jaką znamy ze świata fizycznego, co jest często spotykane w starszych mediach. Nawet produkcje w rodzaju symulatorów często tego nie robią. Dlatego siłą rzeczy trudno wśród tych niewielu przykładów znaleźć stereotypowo przedstawione postacie niepełnosprawne $\mathrm{w}$ rozumieniu właściwym dla telewizji, kina czy książek. Owszem, jeśli przyjmiemy bardzo szerokie rozumienie tego pojęcia, to da się pod nie podciągnąc growych szaleńców, bandytów, morderców czy zbrodniarzy, z którymi często gracze walczą - tu znów można nawiązać do Barnesa i pokazywania niepełnosprawnych w kontekstach kryminalnych. Wtedy poziom fabularnych uproszczeń i wzorowania się na ogranych motywach okazuje się bardzo wysoki i niestety zazwyczaj krzywdzący dla wizerunku danej grupy. W tym kontekście warto też odwołać się do wydawanej od 2000 roku serii The Sims. Kolejne części tego niezwykle popularnego (łączna sprzedaż liczona w setkach milionów sztuk) symulatora życia dawały możliwość zaimplementowania zjawiska niepełnosprawności $\mathrm{w}$ wirtualnym

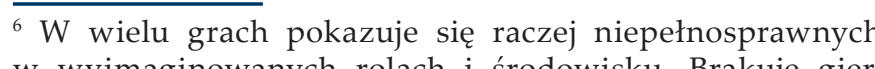
w wyimaginowanych rolach i środowisku. Brakuje gier,
w których ważny element to proces radzenia sobie z blemami wynikajacymi bezpośrednio z niepełnosprawności. To częste ukazywanie bohaterów niepełnosprawnych w perspektywie superbohaterskiej może z jednej strony prowadzić do wzmocnienia ich wizerunku i odgrywanej roli, jednak zazwyczaj oznacza też oderwanie od codzienneg i typowego doświadczenia, co utrudnia przedstawianie re alistycznych obrazów i zmagań z niepełnosprawnościa. Gr maja potencjał do głebbszego niż tradycyjne media i bardzie spersonalizowanego prezentowania specyfiki chorób czy
dolegliwości, ale zazwyczaj urzeczywistnia się to w produkcjach niszowych, czyli o niskim poziomie społecznego oddziaływania. uniwersum, które próbuje (oczywiście w mocnym uproszczeniu) replikować rutynę dnia codziennego. Niestety, ogólny rozwój technologii, samej gry, jak i jej elementów nie doprowadziły do poszerzenia zakresu prezentowanych osobowości czy fizyczności simów w kierunku bardziej różnorodnych (włączając $\mathrm{w}$ to różne niesprawności) modeli. Pomimo licznych dyskusji fanów i zgłaszanych postulatów o konieczności zmiany tego stanu, producenci gry pozostają zamknięci na taką możliwość. Być może $\mathrm{w}$ obawie o uwikłanie serii w tematykę wymykająca się reprodukowanemu w The Sims wzorcowi radosnej konsumpcji, przerywanej budowaniem raczej prostych i powierzchownych relacji. Dlatego kluczowym pytaniem pozostaje to o motywacje twórców. To znaczy, na ile wymienione $\mathrm{w}$ analizie przykłady wynikają z głęboko przemyślanego i celowego procesu produkcyjnego, w którym niepełnosprawność stanowi punkt wyjścia lub przynajmniej istotny element projektu gry, a na ile są to rozwiązania przygodne, implementowane na późniejszym etapie produkcji. To ważne, bo jeśli kwestia stanu fizycznego lub psychicznego postaci jest istotna od wczesnego etapu realizacji gry - tak jak ma to miejsce chociażby w Hellblade: Senua's Sacrifice - to efek-

\section{Bibliografia}

Aarseth Espen J. (1997) Cybertext: Perspectives on Ergodic Literature. Baltimore: The Johns Hopkins University Press.

Alankus Gazihan I in. (2010) Towards Customizable Games for Stroke Rehabilitation. „Therapy and Rehabilitation”, vol. 10-15, s. 2113-2122. Atkinson Matthew T. i in.(2006) Making the mainstream accessible: redefining the game [w:] Sandbox '06: Proceedings of the 2006 ACM SIGGRAPH Symposium on Videogames, New York [do- tem powinno być pogłębione i lepiej zrealizowane (także $\mathrm{w}$ warstwie reguł gry i powiązania $\mathrm{z}$ kluczowymi mechanikami) przedstawienie bohatera z niepełnosprawnością, które jest nieosiągalne dla starszych mediów. Natomiast odmienne podejście może skutkować bohaterami, w których przypadku ten wymiar ich tożsamości można byłoby bez konsekwencji zastąić zupełnie innym, co wydaje nam się zupełnie możliwe $\mathrm{w}$ przypadku chociażby Jade z Fahrenheit. Ostatecznie należy oczekiwać, że gry wideo doczekają się w przyszłości wielu interesujących postaci z niepełnosprawnościami, a stan obecny stanowi konieczny etap przejściowy. To ważne nie tylko z perspektywy - ujmijmy to - dojrzewania gier cyfrowych, ale też samych graczy, szczególnie tych niepełnosprawnych, dla których wzrost inkluzywności tego medium oznaczałby zwiększone szanse na spotkanie wirtualnych bohaterów, z którymi można czy warto się utożsamiać. Mamy nadzieję, że niniejszy tekst stanowić będzie nie tylko inspirację do dalszych badań wśród badaczy problematyki niepełnosprawności, ale też zachętę dla twórców do projektowania gier bardziej różnorodnych, inkluzywnych i spełniających potrzeby osób z niepełnosprawnościami.

stęp 29.10.2017 r.]. Dostępny w Internecie: https://pdfs.semanticscholar.org/122e/c426f9e3357c5f770a1fc5202fbd9ab7a423.pdf.

Babbie Earl (2004) Badania spoteczne w praktyce. Przełożył Witold Betkiewicz i in. Warszawa: PWN.

Barnes Colin (1992) Disabling Imagery and the Media. An Exploration of the Principles for Media Representations of Disabled People. The First in a Series of Reports. The British Council of Organizations of 
Disabled People, Halifax: Ryburn Publishing [dostęp 25.10.2017 r.]. Dostępny w Internecie: http://disabilitystudies.leeds.ac.uk/ files/library/Barnes-disabling-imagery.pdf

Barnes Colin (2010) A Brief History of Discrimination and Disabled People [w:] Davis J. Lennard, ed., The Disability Studies Reader. New York, London: Routledge, s. 20-32.

Bei Yuan, Folmer Eelke, Harris Frederick C. (2011) Game Accessibility: A Survey. „Universal Access in the Information Society", vol. 10, s. 81-100.

Bierre Kevin i in. (2005) Whitepaper: Game not over: Accessibility issues in video games [dostęp 1.01.2017 r.]. Dostępny w Internecie: http://www.igda.org/accessibility/hcii2005 gac.pdf,

Bobrowski Michał i in. (2017) Kondycja Polskiej Branży Gier Wideo 2017 [dostęp 1.03.2018 r.]. Dostępny w Internecie: https://www. cdprojekt.com/pl/wp-content/uploads-pl/2016/03/kondycja-polskiej-branzy-gier17.pdf.

Bogost Ian (2007) Persuasive Games. The Expressive Power of Videogames. London: The MIT Press.

Davis Lennard J. (1995) Enforcing Normalcy: Disability, Deafness and the Body. New York: Verso.

DeFleur Melvin L., Dennis Everette M. (1996) Understanding mass communication. Boston: Houghton Miffin Co.

Dietz, Tracy L. (1998) An examination of violence and gender role portrayals in video games: Implications for gender socialization and aggressive behavior. „Sex Roles”, vol. 38, s. 425-442.

Dippel Anne, Fizek Sonia (2017) Ludification of Culture [w:] Gertraud Koch, ed., The significance of play and games in everyday practices of the digital era. Digitalisation: Theories and Concepts for Empirical Cultural Research. Abington: Routledge, s. 276-292.

Dom (2014) The independent AAA Proposition [dostęp 22.10.2017 r.]. Dostępny w Internecie: http://www.hellblade.com/the-independent-aaa-proposition/

Douglas Mary (2007) Czystość i zmaza. Przełożyła Marta Bucholc. Warszawa: Państwowy Instytut Wydawniczy.
ESA (2005) Essential Facts About the Computer and Video Game Industry 2005 [dostęp 1.03.2018 r.]. Dostępny w Internecie https://pl.scribd.com/document/125495226/ESA-EssentialFacts-2005,

ESA (2017) Essential Facts About the Computer and Video Game Industry 2017 [dostęp 01.03.2018 r.]. Dostępny w Internecie: http://www.theesa.com/wp-content/uploads/2017/04/EF2017 FinalDigital.pdf

Flynn Sheryl M., Lange Belinda S. (2010) Games for the rehabilitation the voice of the players [w:] International Conference Disability, Virtual Reality \& Associated Technologie (ICDVRAT 2010), s. 185-194 [dostęp 27.10.2017 r.]. Dostępny w Internecie: http://ict.usc.edu/pubs/Games\%20for\%20rehabilitation-\%20the\%20voice\% 20of\%20 the\%20players.pdf.

Frasca Gonzalo (2003) Simulation versus Narrative: Introduction to Ludology [w:] Mark J.P. Wolf, Bernard Perron, eds., The Video Game Theory Reader 1st Edition. London: Routledge, s. 221-235.

Gałuszka Damian (2017) Gry wideo w perspektywie potrzeb osób niepetnosprawnych [w:] Jakub Niedbalski, Mariola Racław, Dorota Żuchowska-Skiba, red., Oblicza niepetnosprawności w teorii i praktyce. Łódź: Wydawnictwo Uniwersytetu Łódzkiego, s. 327-355.

Goffman Erving (2005) Piętno, czyli rozważania o zranionej tożsamości. Przełożyły Joanna Tokarska-Bakir, Aleksandr Dzierżyńska. Gdańsk: Gdańskie Wydawnictwo Psychologiczne.

Grammenos Dimitris (2008) Game over: learning by dying [w:] CH '08: Proceeding of the twenty-sixth annual SIGCHI Conference on Human Factors in Computing Systems. New York: ACM, s. 1443-1452 [dostęp 22.10.2017 r.]. Dostępny w Internecie: https://wiki.cc.gatech.edu/designcomp/images/8/8d/P1443grammenos.pdf.

Hocking Clint (2007) Ludonarrative Dissonance in Bioshock [dostęp 27.10.2017 r.]. Dostępny w Internecie: http://clicknothing typepad.com/click_nothing/2007/10/ludonarrative-d.html.

Hunt Paul (1996) A critical condition [w:] Paul Hunt, ed., Stigma: the Experience of Disability. London: Geoffrey Chapman, s. 145-159.
Ivory James D. (2013) Video Games as a Multifaceted Medium: A Review of Quantitative Social Science Research on Video Games and a Typology of Video Game Research Approaches. „Review of CommunicationResearch", no. 1(1), s. 31-68.

Kriegel Leonard (1987) The cripple in literature [w:] Alan Gartner, Tom Joe, eds., Images of the Disabled, Disabling Images. New York: Praeger, s. 31-46.

KRRiT (2014) Wizerunek osób niepetnosprawnych w telewizji [dostęp 24.03.2018 r.]. Dostępny w Internecie http://www.krrit.gov.pl/krrit/ aktualnosci/news,1449, wizerunek-osob-niepelnosprawnych-wtelewizji.html.

Lange Belinda S. i in. (2010) Development of an interactive game-based rehabilitation tool for dynamic balance training. „Topics in Stroke Rehabilitation", vol. 17(5), s. 345-352.

Longmore Paul K. (1987) Screening stereotypes, images of disabled people in television and motion pictures [w:] Alan Gartner, Tom Joe, eds., Images of the Disabled, Disabling Images. New York: Praeger, s. 65-78.

Martins Nicole i in. (2009) A content analysis of female body imagery in video games. „Sex Roles", no. 61, s. 824-883.

Mäyrä Frans (2017) Pokémon GO: Entering the Ludic Society. "Mobile Media \& Communication", vol. 1(5), s. 47-50.

Melosik Zbyszko (2004) Kultura popularna jako czynnik socjalizacji [w:] Zbigniew Kwieciński, Bogusław Śliwerski, red., Pedagogika, t. 2. Warszawa: PWN, s. 68-93.

Mudyń Krzysztof (2002) Stereotyp [w:] Zespół redakcyjny pod kierunkiem Władysława Kwaśniewicza, red., Encyclopedia Socjologii. Tom IV. Warszawa: Oficyna Wydawnicza, s. 119-120.

Nitsche Michael (2008) Video game spaces: Image, play, and structure in $3 \mathrm{D}$ game worlds. Cambridge, London: MIT Press.

Ostrowska Antonina (2015) Niepetnosprawni w społeczeństwie 1993-2013. Warszawa: Wydawnictwo IFIS PAN.

Podgórska-Jachnik Dorota (2013) Deprecjacja osób z niepetnosprawnościa w dyskursie publicznym za pośrednictwem mediów [w:]
Zenon Gajdzica, red., Człowiek z niepetnosprawnością w rezerwacie przestrzeni publicznej. Kraków: Impuls, s. 65-110.

Raessens Jozef Frederik F. (2010) Homo Ludens 2.0. The Ludic Turn in Media Theory. Utrecht: Utrecht University Press.

Robertson Margaret (2010) Can't Play, Won't Play. In Hide and Seek [dostęp 10. 10.2017 r.]. Dostępny w Internecie: http://hideandseek.net/2010/10/06/cant-play-wont-play

Ruść Iwona (2007) Wizerunek osób z ograniczona sprawności w mediach [w:] Anna Brzezińska, Zbigniew Woźniak, Konrad Maj, red., Osoby z ograniczona sprawnóscia na rynku pracy. Warszawa: Wyd. SWPS „Academica”, s. 135-140.

Sahaj Tomasz (2013) Niepetnosprawuność i niepełnosprazuni wo mediach. Warszawa: Instytut Rozwoju Służb Społecznych.

Sahaj Tomasz (2016) Niepetnosprawni jako kreatorzy, odbiorcy i użytkownicy mediów [w:] Elżbieta Zakrzewska-Manterys, Jakub Niedbalski, red., Pasjonaci kreatorzy twórcy. Ludzie niepethosprawni jako artyści, sportowcy, animatorzy mediów. Łódź: Wydawnictwo Uniwersytetu Łódzkiego, s. 109-158.

Sahaj Tomasz (2017) Repozycjonowanie osób niepetnosprawnych w przekazach medialnych na przykładach wybranych kampanii społecznych. "Acta Universitatis Lodziensis. Folia Sociologica”, nr 60, s. 183-199.

Sandlund Marlene, McDonough Suzanne, Häger-Ross Charlotte (2009) Interactive computer play in rehabilitation of children with sensorimotor disorders: a systematic review. „Developmental Medicine and Child Neurology", vol. 51, s. 173-179.

Shakespeare Tom W. (1994) Cultural representations of disabled people: dustbins for disavowal? „Disability and Society”, vol. 9, s. 283-299.

Shearer Ann (1981) Disability.Whose Handicap? Oxford: Blackwell.

Stiker Henri-Jacques (1999) A History of Disability. Ann Arbor: University of Michigan Press.

Struck-Peregończyk Monika (2013) Wizerunek osób niepetnosprawnych w środkach masowego przekazu - zarys zjawiska. 
Kwartalnik Internetowy „Komunikacja Społeczna”, t. 8, s. 22-31.

Turner Victor W. (1969) The Ritual Process. Structure and AntiStructure. Chicago: Aldine Publishing Company.

Walter Natalia (2011) Tyflointernet - niewidomi w globalnej wiosce. Neodidagmata", t. 31/32, s. 127-136.
Zichermann Gabe, Linder Joselin (2013) The Gamification Revolution: How Leaders Leverage Game Mechanics to Crush the Competition. New York: McGraw-Hill.

Zielińska Jolanta (2012) Przykłady wykorzystania nowoczesnych technologii w komunikacji alternatywnej [dostęp 26.10.2017 r.] Dostępny w Internecie: http://www.ktime.up.krakow.pl/ symp2012/referaty_2012_10/zielinska. pdf,

\section{Cytowanie}

Gałuszka Damian, Żuchowska-Skiba Dorota (2018) Niepetnospraawność w grach wideo - omówienie na przykkadach wybranych wirtualnych postaci. „Przegląd Socjologii Jakościowej”, t. 14, nr 3, s. 92-112 [dostęp dzień, miesiąc, rok]. Dostępny w Internecie: «www. przegladsocjologiijakosciowej.org. DOI: http://dx.doi.org/10.18778/1733-8069.14.3.06.

\section{Disability in Video Games-An Overview Based on Selected Virtual Characters}

Abstract: Images of disability present in the media have a significant impact on the perception of people with disabilities. They shape stereotypical ideas that translate into the attitudes and expectations that a large part of society has for people with disabilities. Previous research has focused on showing images of people with disabilities in traditional media. Meanwhile, in modern popular culture, new media, including video games, play an increasing role. Today, it is important to examine the ways in which characters with disabilities are portrayed in video games.

The main aim of this article is to reconstruct typical images of disability in video games. This will show how the built-in images fix or change existing stereotypes. Video games were selected in which disabled heroes appeared. The study was based on the analysis of cultural codes. This method was adapted for the study of a specific medium-video games. They engage the user in the process of creating the hero and the actions he takes in the game world.

Keywords: video games, disability, stereotypes 